\title{
A szervesanyagra vonatkozó osztályozási információk a hazai genetikus talajosztályozási rendszer útmutatóiban
}

\author{
FuCHS Márta, SzEGi Tamás, *CSORBA Ádám, MichÉLI Erika \\ Szent István Egyetem, Környezettudományi Intézet, \\ Talajtani és Agrokémiai Tanszék, Gödöllö \\ (Beérkezett: 2018.11.16.; Elfogadva: 2019.05.07.)
}

\section{Bevezetés}

A szerves szén igen jelentős összetevője a talajoknak. Meghatározza a talajok számos fizikai, kémiai és biológiai tulajdonságát és sokrétủ környezeti funkcióit, többek között termékenységét, vízszürő-, és szolgáltató képességét, pufferkapacitását, vagy a biológiai sokféleség megőrzésében játszott szerepét. Mivel a talajok a legjelentősebb szárazföldi széntározók, igen fontos szerepük van a szén globális körforgalmában, így a klímaváltozásban is (LAL, 2004a, 2004b; VÁRALLYAY, 2008). Mindezek alapján napjainkban nagy igény mutatkozik talajok szerves anyagára és annak változására vonatkozó adatokra.

A modern osztályozási rendszerekben a szerves szén mennyiségi és mélységi megjelenése diagnosztikus kategóriáknak, és magasabb rendszertani egységeknek is gyakran alapja (MicHÉLI et al., 2014). Diagnosztikus szemléletủ hazai talajosztályozási rendszerünk kidolgozásakor (MICHÉLI et al., 2015) különös figyelmet szenteltünk a szervesanyag-tartalomnak, mint osztályozási feltételnek.

A szervesanyaggal kapcsolatos diagnosztikus egységek meghatározásának első lépéseként részletesen áttekintettük a hazai genetikus osztályozáshoz kapcsolódó alapirodalmakban (SZABOLCS, 1966; JASSÓ et al., 1989) megjelenő, az egyes talajtípusok szervesanyag tartalmára, ill. morfológiai tulajdonságaira (pl. humuszos réteg vastagsága, szín, szintek közötti átmenet) vonatkozó információkat. Az osztályozási rendszer genetikus szemléletéből adódóan ezen információk jelentős része szubjektív és erősen leíró jellegü, a számszerü határértékekkel jellemzett, főképp alacsonyabb szintủ (ún. változati) tulajdonságok pedig fötípusonként, típusonként, és az egyes források (STEFANOVITS, 1999; SzABOLCS, 1966; JASSÓ et al., 1989) között is jelentősen eltérnek.

Jelen cikk keretében áttekintjük és értékeljük a hazai genetikus rendszer szervesanyaggal kapcsolatos osztályozási információit, megalapozva a diagnosztikus szemléletủ hazai talajosztályozási rendszerünk szervesanyagtartalommal kapcsolatos osztályozási kritériumainak kidolgozását.

*Levelező szerző: CSORBA ÁDÁM, Szent István Egyetem, Környezettudományi Intézet, Talajtani és Agrokémiai Tanszék, 2100 Gödöllö, Páter K. u. 1.

E-mail: csorba.adam@mkk.szie.hu 


\section{Problémafelvetés}

A talajok szervesanyag-tartalma az ásványi frakcióhoz viszonyított kis mennyiségi megjelenése ellenére az egyik legjelentősebb tényező a talajok sokrétű funkcióinak kialakításában és müködésében, valamint a globális szénkörforgalom meghatározó elemeként a klímaváltozás hatásainak mérséklésében is.

Ennek ellenére a talajosztályozási rendszerekkel kapcsolatban megfogalmazott átalános kritika, hogy nagyobb hangsúlyt fektetnek a viszonylag stabilnak tekinthető altalaj tulajdonságokra, és kissebb figyelmet fordítanak az időben és térben is nagy változatosságot mutató feltalajra és tulajdonságaira (SPAARGAREN \& NACHTERGAELE, 1998; FUCHS et al., 2005). A feltalaj tulajdonságainak, különösen szervesanyag tartalmának ismerete azonban elengedhetetlen a sikeres, és fenntartható gazdálkodás megtervezéséhez és müködtetéséhez.

A hivatalos nemzetközi (SOIL SURVEY STAFF, 1999; IUSS WORKING GROUP WRB, 2006; 2015), és a legtöbb nemzeti (pl. orosz, kínai, cseh, román vagy a lengyel) talajosztályozási rendszer ún. diagnosztikus szemlélet szerint, szigorú definíciók és számszerü kritériumok alapján határozza meg a talajok meghatározó jellemzőit (az ún. diagnosztikus szintjeit, tulajdonságait és anyagait), és kulcs segítségével osztályozza a talajokat. A nemzetközi rendszerek szervesanyagtartalomra vonatkozó diagnosztikus kategóriáit FUCHS et al. (2005) és MichÉLI et al. (2014) tekintette át.

A hazai, genetikai alapokon nyugvó talajosztályozási rendszerünk (SZABOLCS, 1966; STEFANOVITS, 1972; JASSÓ, 1989) a talajokat fejlődésükben vizsgálja, és genetikai szemléletéből adódóan az osztályozás definíciói és döntési szabályai sok szubjektív elemet tartalmaznak, amely megnehezíti a talajok egyértelmű elkülönítését, elnevezését és nemzetközi megfeleltetését (MICHÉLI et al., 2006).

A szervesanyag-tartalommal kapcsolatos osztályozási információk az egyes genetikus osztályozási egységek definícióiban és leírásaiban a hazai gyakorlatban alkalmazott Szabolcs István szerkesztésében megjelent (1966) „A genetikus üzemi talajtérképezés módszerkönyve" c. OMMI kiadvány, és a JASSó és munkatársai (1989) által összeállított „Útmutató a nagy méretarányú országos talajtérképezés végrehajtásához" c. kiadvány alapján kerültek áttekintésre.

$\mathrm{Az}$ áttekintett típusokra vonatkozó eredményeinket fötípusonként csoportosítva, táblázatos formában mutatjuk be (1-9. táblázat).

\section{Láptalajok}

Genetikus osztályozási rendszerünkben a láptalajok főtípusára az állandó, vagy az év nagyobb részében vízborítás hatása alatt képződő, igen nagy szervesanyag tartalmú, tőzeges, vagy kotus rétegek jelenléte a jellemző, amely által élesen elkülönülnek a többi, ásványi fötípustól.

Bár a láptalajok legfőbb elkülönítő tényezöje a kiemelkedő szervesanyagtartalom, sem fötípus, sem alacsonyabb szinten nem áll rendelkezésre pontos, számszerü kritérium arra vonatkozóan, hogy hány százalék szervesanyagtartalomtól tekinthetünk egy talajt lápnak, valamint a további elkülönítés alapjául 
szolgáló tőzeges, ill. kotus rétegek meghatározása is leíró jellegü, és forrásonként eltérő (1. táblázat).

\section{1. táblázat}

A láptalajok szervesanyagra vonatkozó osztályozási információi a hazai genetikus osztályozási rendszer útmutatóiban (SZABOLCS, 1966; JASSó et al., 1989 alapján)

\begin{tabular}{|c|c|c|}
\hline \multirow{5}{*}{$\begin{array}{l}\text { A } \\
\text { láptalajok } \\
\text { talajtípusai }\end{array}$} & \multicolumn{2}{|c|}{ Szervesanyagra vonatkozó osztályozási információk } \\
\hline & $\begin{array}{l}\text { Nagyméretarányú } \\
\text { útmutató } \\
\text { JASSÓ et al. (1989) }\end{array}$ & $\begin{array}{c}\text { Üzemi genetikus útmutató } \\
\text { SZABOLCS (1966) }\end{array}$ \\
\hline & talajtípus & talajtípus \\
\hline & altípus & altípus \\
\hline & & változat \\
\hline $\begin{array}{l}\text { Mohaláp } \\
\text { (ML) }\end{array}$ & $\begin{array}{l}\text { tőzegmoha } \\
\text { elhumuszosodása }\end{array}$ & tőzegmoha elhumuszosodása \\
\hline & - & \\
\hline Rétláp (RL) & tőzegesedés & tőzegesedés \\
\hline & - & $\begin{array}{l}\text { tőzegláp - tőzeg }>50 \mathrm{~cm} \\
\text { tőzegesláp - tőzeg }<50 \mathrm{~cm} \\
\text { kotus tőzegláp - > } 50 \mathrm{~cm} \text { rosttőzeg felett kotu } \\
\text { kotusláp - csak kotu } \\
\text { sekély rétegü - kotu vagy tőzeg }<50 \mathrm{~cm} \\
\text { közepes rétegü - kotu vagy tőzeg } 50-100 \mathrm{~cm} \\
\text { mély rétegü - kotu vagy tőzeg }>100 \mathrm{~cm} \\
\text { ásványosodott kotu - szervesanyag }<25 \% \\
\text { iszaposodott tőzeg - szervesanyag <50\% }\end{array}$ \\
\hline Lecsapolt & kotusodás & Szerves részek erőteljesebb ásványosodása \\
\hline $\begin{array}{l}\text { és } \\
\text { telkesített } \\
\text { rétláp } \\
\text { (LTRL) }\end{array}$ & $\begin{array}{l}\text { lecsapolt tőzegláp - tőzeg > } \\
50 \mathrm{~cm} \\
\text { lecsapolt tőzeges láp - } \\
\text { tőzeg }<50 \mathrm{~cm} \\
\text { lecsapolt kotusláp - kotu } \\
\text { szervesanyag }>10 \%\end{array}$ & $\begin{array}{l}\text { lecsapolt tőzegláp - tőzeg }>50 \mathrm{~cm} \\
\text { lecsapolt tőzegesláp - tőzeg }<50 \mathrm{~cm} \\
\text { lecsapolt kotusláp - > } 50 \mathrm{~cm} \text { rosttőzeg felett kotu } \\
\begin{array}{l}\text { sekély rétegü - kotu vagy tőzeg }<50 \mathrm{~cm} \\
\text { közepes rétegü - kotu vagy tőzeg } 50-100 \mathrm{~cm} \\
\text { mély rétegü - kotu vagy tőzeg }>100 \mathrm{~cm}\end{array} \\
\text { ásványosodott kotu - szervesanyag }<25 \% \\
\text { iszaposodott tözeg - szervesanyag }<50 \%\end{array}$ \\
\hline
\end{tabular}

A láptalajok genetikus osztályozása és nevezéktana problémáiról, valamint a hazai szerves talajok diagnosztikus osztályozására vonatkozó javaslatáról MICHÉLI et al. (2017) dolgozatában található részletes leírás. 


\section{2. táblázat}

A váztalajok szervesanyagra vonatkozó osztályozási információi a hazai genetikus osztályozási rendszer útmutatóiban (SZABOLCS, 1966; JASSÓ et al., 1989 alapján)

\begin{tabular}{|c|c|c|}
\hline \multirow{5}{*}{$\begin{array}{l}\text { A } \\
\text { váztalajok } \\
\text { talajtípusai }\end{array}$} & \multicolumn{2}{|c|}{ Szervesanyagra vonatkozó osztályozási információk } \\
\hline & $\begin{array}{c}\text { Nagyméretarányú útmutató } \\
\text { JASSÓ et al. (1989) }\end{array}$ & $\begin{array}{l}\text { Üzemi genetikus útmutató } \\
\text { SZABOLCS (1966) }\end{array}$ \\
\hline & Talajtípus & talajtípus \\
\hline & Altípus & altípus \\
\hline & & változat \\
\hline Köves & - & - \\
\hline $\begin{array}{l}\text { sziklás } \\
\text { váztalaj } \\
\text { (KSz) }\end{array}$ & - & \\
\hline Kavicsos & - & - \\
\hline váztalaj (K) & - & $-\cdots$ \\
\hline $\begin{array}{l}\text { Földeskopár } \\
\text { (Barren }\end{array}$ & - & \begin{tabular}{|l}
$\begin{array}{l}\text { vékony rétegben } \\
\text { humuszosodás }\end{array}$ \\
\end{tabular} \\
\hline earth) & - & $\begin{array}{l}\text { humuszos réteg vastagsága szerint: } \\
\text { vékony- <20 cm (A+B szint) } \\
\text { sekély- } 20-40 \mathrm{~cm}(\mathrm{~A}+\mathrm{B} \text { szint }) \\
\text { humusztartalom szerint: } \\
\text { erősen humuszos - >2\% humusz }\end{array}$ \\
\hline $\begin{array}{l}\text { Futóhomok } \\
\text { (FH) }\end{array}$ & humuszos réteg $<30 \mathrm{~cm}$, humusz $<1 \%$ & \begin{tabular}{|l}
$\begin{array}{l}\text { humuszosodás igen } \\
\text { mutatkozhatnak }\end{array}$ \\
\end{tabular} \\
\hline & $\begin{array}{l}\text { lepelhomok - } 150 \mathrm{~cm} \text {-ig eltemetett } \\
\text { (humuszos vagy humusz nélküli) réteg } \\
\text { található } \\
\text { tereprendezett, nyesett felszínü }-1 \% \\
\text { alatti humusztartalmú antropogén } \\
\text { talajok }\end{array}$ & (n) \\
\hline $\begin{array}{l}\text { Humuszos } \\
\text { homok } \\
\text { (HH) }\end{array}$ & $\begin{array}{l}\text { humuszos réteg }\langle 30 \mathrm{~cm} \text {, humusz }>1 \% \text {; } \\
\text { vagy } \\
\text { humuszos réteg }>30 \mathrm{~cm} \text {, humusz }> \\
0,5 \%\end{array}$ & $\begin{array}{l}\text { humusz réteg ritkán mélyebb mint } 40- \\
50 \mathrm{~cm} \text {, humusztartalom ritkán több } \\
\text { mint } 1,5 \%\end{array}$ \\
\hline & $\begin{array}{l}\text { többrétegú }-150 \mathrm{~cm} \text {-ig eltemetett } \\
\text { (humuszos vagy humusz nélküli) réteg } \\
\text { található }\end{array}$ & $\begin{array}{l}\text { humuszos réteg vastagsága szerint: } \\
\text { sekély }-<20 \mathrm{~cm}(\mathrm{~A}+\mathrm{B} \text { szint }) \\
\text { közepes }-20-50 \mathrm{~cm} \\
\text { mély }->50 \mathrm{~cm} \\
\text { humusztartalom szerint: } \\
\text { gyengén humuszos } \quad-<1,5 \% \\
\text { humusz }\end{array}$ \\
\hline
\end{tabular}




\section{Váztalajok}

A váztalajok fötípusában öt fejlődésében korlátozott, egymástól jelentősen eltérő talajtípus került meghatározásra. Ezek szervesanyaggal kapcsolatos osztályozási információit a 2. táblázat foglalja össze.

A köves-sziklás-, és kavicsos váztalajok esetében egyik sem, a földeskopár talajtípus esetében csak az „Üzemi genetikus útmutató” (SzABOLCS, 1966) tartalmaz szervesanyagra vonatkozó osztályozási információt - itt a típus szinten megadott, leíró jellegü információ (,vékony rétegben enyhe humuszosodás”) azonban nincs összehangban a változati szinten meghatározott tulajdonságokkal, amely alapján az akár 2\%-nál nagyobb humusztartalmú, és $40 \mathrm{~cm}$ vastag humuszos réteggel rendelkező talajok is besorolhatók például a földeskopár típusába.

A futóhomok és humuszos homok típusok esetén a „Nagyméretarányú útmutató" (JASSÓ et al., 1989) már talajtípus szinten pontos, a humuszos réteg vastagságára és a humusztartalomra vonatkozó határértékeket használ, ezek azonban nincsenek összhangban az „Üzemi genetikus útmutató”-ban (SZABOLCS, 1966) változati szinten megadott értékekkel (2. táblázat).

Itt fontosnak tartjuk kiemelni, hogy ásványi talajok esetében a „humuszos réteg vastagsága” ill. a „humusztartalom” szerinti osztályozás meghatározása sem egyértelmű. A ,humuszos réteg vastagságának” megállapítása erősen szubjektív (humuszos réteg alatt az „egyenletesen elhumuszosodott, vagy enyhén csökkenő humusztartalmú réteg"-et értik az útmutatók), sem az elvárt szín, sem a megengedett átmenet vastagsága nem definiált. A „humusztartalom” szerinti osztályozáshoz csak az „Üzemi genetikus útmutató” (SzABOLCS, 1966) ad iránymutatást, de a meghatározás különböző talajok esetében eltérő (általában a felső $20 \mathrm{~cm}$-es talajréteg humusztartalmára, vagy a szántott rétegre, erdőtalajoknál az A1 szintre, 20 cm-nél vékonyabb humuszos réteg esetén a „meghatározott” humuszos rétegre vonatkozik).

\section{Közethatású talajok}

A Kőzethatású talajok típusait általában erőteljes humuszosodás jellemzi, melyek meghatározása típusonként elég változatos képet mutat: leíró jellegü és számszerü adatok is előfordulnak - ez utóbbiak megfogalmazása (pl. „lehet jóval több”) lehetôséget biztosít szubjektív döntések meghozatalára. Az „Üzemi genetikus útmutató" (SZABOLCS, 1966) mély (> $100 \mathrm{~cm}$ ) humuszréteg vastagságra vonatkozó változati tulajdonságai több típus esetében ellentétben állnak a fötípus „sekély termőrétegü” alapkoncepciójával. Humusztartalom jelzésére (változati szinten) csak a humuszkarbonát, és rendzina talajok esetében van mód - ez utóbbi talajtípus „erősen humuszos” változati tulajdonsága által jelzett (5-20\% közötti) humusztartomány túl tág a talaj szervesanyag tartalmának objektív megítéléséhez.

A fötípusba tartozó talajtípusok szervesanyagra vonatkozó osztályozási információit a 3. táblázat foglalja össze. 


\section{3. táblázat}

A kőzethatású talajok szervesanyagra vonatkozó osztályozási információi a hazai genetikus osztályozási rendszer útmutatóiban (SZABOLCS, 1966; JASSó et al., 1989 alapján)

\begin{tabular}{|c|c|c|}
\hline \multirow{5}{*}{$\begin{array}{l}\text { A } \\
\text { kőzethatású } \\
\text { talajok } \\
\text { talajtípusai }\end{array}$} & \multicolumn{2}{|c|}{ Szervesanyagra vonatkozó osztályozási információk } \\
\hline & $\begin{array}{c}\text { Nagyméretarányú útmutató } \\
\text { JASSÓ et al. (1989) }\end{array}$ & $\begin{array}{l}\text { Üzemi genetikus útmutató } \\
\text { SZABOLCS (1966) }\end{array}$ \\
\hline & \multirow{3}{*}{$\begin{array}{l}\text { talajtípus } \\
\text { altípus }\end{array}$} & talajtípus \\
\hline & & altípus \\
\hline & & változat \\
\hline \multirow[t]{3}{*}{$\begin{array}{l}\text { Humusz- } \\
\text { karbonát talaj } \\
(\mathrm{HK})\end{array}$} & $\begin{array}{l}3-4 \% \text { mélységgel fokozatosan } \\
\text { csökkenő humusztartalmú réteg } \\
\text { figyelhető meg }\end{array}$ & $\begin{array}{l}\text { humusztartalmuk többnyire nagy és } \\
\text { lefelé fokozatosan csökken }\end{array}$ \\
\hline & \multirow[t]{2}{*}{-} & - \\
\hline & & $\begin{array}{l}\text { humuszos réteg vastagsága szerint: } \\
\text { sekély }-<50 \mathrm{~cm}(\mathrm{~A}+\mathrm{B} \text { szint }) \\
\text { közepes }->50 \mathrm{~cm} \\
\text { humusztartalom szerint: } \\
\text { gyengén humuszos }-<2 \% \text { humusz } \\
\text { erősen humuszos }->5 \% \text { humusz }\end{array}$ \\
\hline \multirow[t]{3}{*}{ Rendzina $(\operatorname{Re})$} & $\begin{array}{l}\text { erőteljes humuszosodás, sekély és } \\
\text { mélyebb humuszos réteg is előfordul }\end{array}$ & $\begin{array}{l}\text { szervesanyag } 5-10 \% \text { de lehet jóval } \\
\text { több is }\end{array}$ \\
\hline & \multirow[t]{2}{*}{ - } & 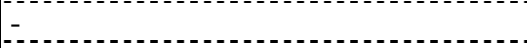 \\
\hline & & $\begin{array}{l}\text { humuszos réteg vastagsága szerint: } \\
\text { sekély }-<50 \mathrm{~cm} \\
\text { közepes }-50-100 \mathrm{~cm} \\
\text { mély }->100 \mathrm{~cm} \\
\text { humusztartalom szerint: } \\
\text { gyengén humuszos }-<2 \% \text { humusz } \\
\text { erősen humuszos }-5-20 \% \text { humusz } \\
\text { humuszgazdag - humusz }>20 \%\end{array}$ \\
\hline \multirow[t]{3}{*}{$\begin{array}{l}\text { Fekete nyirok } \\
\text { (FNy) }\end{array}$} & $\begin{array}{l}\text { szervesanyag } 5-8 \% \text {, a humuszos } \\
\text { réteg vastagsága } 80 \mathrm{~cm} \text { is lehet }\end{array}$ & magas szervesanyag-tartalom \\
\hline & \multirow[t]{2}{*}{-} & \\
\hline & & $\begin{array}{l}\text { humuszos réteg vastagsága szerint: } \\
\text { sekély }-<50 \mathrm{~cm} \\
\text { közepes }-50-100 \mathrm{~cm} \\
\text { mély }->100 \mathrm{~cm}\end{array}$ \\
\hline \multirow[t]{2}{*}{ Ranker (Ra) } & - & - \\
\hline & - & \\
\hline
\end{tabular}

\section{Csernozjom talajok}

A csernozjom talajok meghatározó jellemzője az erős humuszosodás, melynek eredményeképp mély, sötét, fokozatos átmenettel jellemzhető humuszos felszíni szintjük alakul ki. Genetikus osztályozási rendszerünk azonban e felszíni szintnek 
sem a színét, sem mélységét, sem szervesanyag tartalmát nem definiálja pontosan, így e talajok meghatározása is szubjektív (4. táblázat).

A humusztartalom, és a humuszos réteg vastagságának jelzésére csak az „Üzemi genetikus útmutató” (SZABOLCS, 1966) változati szintje biztosít lehetőséget - a humusztartalom kapcsán csak a „gyengén humuszos” jelleg jelezhető. A „gyengén humuszos” tulajdonság azonos értelmezését nehezíti, hogy esetében külön határérték került meghatározásra a homokos-, és annál finomabb textúra esetén. A helyzetet tovább bonyolítja, hogy a csernozjomok felszíni talajszintjének minimális humusztartalma sem került meghatározásra. Így a főtípusnak az „Üzemi genetikus útmutató"-ban (SZABOLCS, 1966) homokos szövetủ talajokra megadott „gyengén humuszos" változati tulajdonsága (humusztartalom < 1,5\%) átfedésbe kerül a Váztalajok főtípusába tartozó humuszos homok talajtípus jellemző (szervesanyag-tartalomra vonatkozó) tulajdonságaival.

\section{4. táblázat}

A csernozjom talajok szervesanyagra vonatkozó osztályozási információi a hazai genetikus osztályozási rendszer útmutatóiban (SZABOLCS, 1966; JASSÓ et al., 1989 alapján)

\begin{tabular}{|c|c|c|}
\hline \multirow{4}{*}{$\begin{array}{l}\text { A } \\
\text { csernozjom } \\
\text { talajok } \\
\text { talajtípusai }\end{array}$} & \multicolumn{2}{|c|}{ Szervesanyagra vonatkozó osztályozási információk } \\
\hline & $\begin{array}{l}\text { Nagyméretarányú } \\
\text { útmutató } \\
\text { JASSÓ et al. (1989) }\end{array}$ & $\begin{array}{l}\text { Üzemi genetikus útmutató } \\
\text { SZABOLCS (1966) }\end{array}$ \\
\hline & talajtípus & talajtípus \\
\hline & altípus & altípus \\
\hline \multirow{2}{*}{$\begin{array}{l}\text { Erdő- } \\
\text { maradványos } \\
\text { csernozjom } \\
\text { (ECs) }\end{array}$} & $\begin{array}{l}\text { Mély, fokozatos alsó határú } \\
\text { humuszos réteg }\end{array}$ & $\begin{array}{l}\text { Erősen humuszos, fokozatos átmenetü A és } \\
\text { B szint }\end{array}$ \\
\hline & - & $\begin{array}{l}\text { humuszos réteg vastagsága szerint: } \\
\text { sekély }-<40 \mathrm{~cm} \\
\text { közepes }-40-80 \mathrm{~cm} \\
\text { mély }->80 \mathrm{~cm} \\
\text { humusztartalom szerint: } \\
\text { gyengén humuszos }-<2 \% \text { humusz }\end{array}$ \\
\hline \multirow{2}{*}{$\begin{array}{l}\text { Mész- } \\
\text { lepedékes } \\
\text { csernozjom } \\
(\mathrm{MCs})\end{array}$} & $\begin{array}{l}\text { humusztartalom az A szintben } \\
2-4 \% \text { a B szintben } 1-3 \% \text {, } \\
\text { fokozatos átmenet }\end{array}$ & - \\
\hline & - & $\begin{array}{l}\text { humuszos réteg vastagsága szerint: } \\
\text { sekély }-<40 \mathrm{~cm} \\
\text { közepes }-40-80 \mathrm{~cm} \\
\text { mély }->80 \mathrm{~cm} \\
\text { humusztartalom szerint: } \\
\text { gyengén humuszos } \quad-<2 \% \quad \text { humusz } \\
\text { homok esetén }<1,5 \%\end{array}$ \\
\hline
\end{tabular}




\begin{tabular}{|c|c|c|}
\hline \multicolumn{3}{|c|}{ 4. táblázat folytatása } \\
\hline \multirow{2}{*}{$\begin{array}{l}\text { Kilúgzott } \\
\text { csernozjom } \\
(\mathrm{KCs})\end{array}$} & $\begin{array}{l}\text { Mély, fokozatos alsó határú } \\
\text { humuszos réteg }\end{array}$ & Mély, fokozatos alsó határú humuszos szint \\
\hline & - & $\begin{array}{l}\text { humuszos réteg vastagsága szerint: } \\
\text { sekély }-<40 \mathrm{~cm} \\
\text { közepes }-40-80 \mathrm{~cm} \\
\text { mély }->80 \mathrm{~cm} \\
\text { humusztartalom szerint: } \\
\text { gyengén humuszos }-<2 \% \text { humusz; homok } \\
\text { esetén }<1,5 \%\end{array}$ \\
\hline \multirow[t]{2}{*}{$\begin{array}{l}\text { Réti } \\
\text { csernozjom } \\
(\mathrm{RCs})\end{array}$} & $\begin{array}{l}\text { A felszíni szint színe sötétebb, } \\
\text { szervesanyag-tartalma } 3-4 \% \text { - } \\
\text { ról hirtelen lecsökken }\end{array}$ & $\begin{array}{l}\text { Magasabb humusztartalmú, sötétebb, rövid } \\
\text { alsó átmenettel }\end{array}$ \\
\hline & - & $\begin{array}{l}\text { humuszos réteg vastagsága szerint: } \\
\text { sekély }-<40 \mathrm{~cm} \\
\text { közepes }-40-80 \mathrm{~cm} \\
\text { mély }->80 \mathrm{~cm}\end{array}$ \\
\hline \multirow[t]{2}{*}{$\begin{array}{l}\text { Öntés (terasz) } \\
\text { csernozjom } \\
\text { (ÖCs) }\end{array}$} & $\begin{array}{l}\text { A feltalaj } 2-4 \% \text { szervesanyag- } \\
\text { tartalma lefelé fokozatosan } \\
\text { csökken }\end{array}$ & - \\
\hline & - & $\begin{array}{l}\text { humuszos réteg vastagsága szerint: } \\
\quad \text { sekély }-<40 \mathrm{~cm} \\
\text { közepes }-40-80 \mathrm{~cm} \\
\text { mély }->80 \mathrm{~cm} \\
\text { humusztartalom szerint: } \\
\text { gyengén humuszos }-<2 \% \text { humusz; homok } \\
\text { esetén }<1,5 \%\end{array}$ \\
\hline
\end{tabular}

\section{Közép- és Délkelet-európai barna erdőtalajok}

A Közép- és Délkelet-európai barna erdőtalajok típusai esetében szintén a genetikus szemléletre jellemző, leíró jellegü információk vannak túlsúlyban a szervesanyag-tartalomra vonatkozóan. A megfogalmazásban gyakori a szubjektivitást növelő „általában” vagy „ritkán több” kifejezések használata (5. táblázat).

Az „Üzemi genetikus útmutató” (SZABOLCS, 1966) humuszréteg vastagságra vonatkozó változati tulajdonságai kapcsán megadott értékek még a főtípuson belül sem harmonizáltak, megnehezítve a rendszer használatát. A humusztartalom jelzése (gyengén-, és erősen humuszos változatok) a fötípuson belül egységes, de a többi fötípussal nem harmonizált. 


\section{5. táblázat}

A Közép- és Délkelet-európai barna erdőtalajok talajok szervesanyagra vonatkozó osztályozási információi a hazai genetikus osztályozási rendszer útmutatóiban

(SZABOLCS, 1966; JASSÓ et al., 1989 alapján)

\begin{tabular}{|c|c|c|}
\hline \multirow{5}{*}{$\begin{array}{l}\text { A Közép- és } \\
\text { Délkelet- } \\
\text { európai } \\
\text { barna } \\
\text { erdőtalajok } \\
\text { talajtípusai }\end{array}$} & \multicolumn{2}{|c|}{ Szervesanyagra vonatkozó osztályozási információk } \\
\hline & \multirow{2}{*}{$\begin{array}{l}\text { Nagyméretarányú útmutató } \\
\text { JASSÓ et al. (1989) } \\
\text { talaitípus }\end{array}$} & $\begin{array}{c}\text { Üzemi genetikus útmutató } \\
\text { SZABOLCS (1966) }\end{array}$ \\
\hline & & talajtípus \\
\hline & \multirow[t]{2}{*}{ altípus } & altípus \\
\hline & & változat \\
\hline \multirow{3}{*}{$\begin{array}{l}\text { Csernozjom } \\
\text { barna } \\
\text { erdőtalaj } \\
\text { (CsBET) }\end{array}$} & $\begin{array}{l}\text { Jól kifejezett mély humuszos } \\
\text { szint, fokozatos átmenettel }\end{array}$ & $\begin{array}{l}\text { Mélyrehatoló, fokozatos átmenetü } \\
\text { humuszosodás }\end{array}$ \\
\hline & \multirow[t]{2}{*}{-} & - \\
\hline & & $\begin{array}{l}\text { humuszos réteg vastagsága szerint: } \\
\text { sekély }-<30 \mathrm{~cm}(\mathrm{~A}+\mathrm{B} \text { szint }) \\
\text { közepes }-30-60 \mathrm{~cm} \\
\text { mély }->60 \mathrm{~cm} \\
\text { humusztartalom szerint: } \\
\text { gyengén humuszos }-<1,5 \% \text { humusz }\end{array}$ \\
\hline \multirow[t]{2}{*}{$\begin{array}{l}\text { Barnaföld } \\
\text { (BF) }\end{array}$} & $\begin{array}{l}\text { A humuszos } A \text { szint általában } \\
20-30 \mathrm{~cm} \text { vastag }\end{array}$ & - \\
\hline & - & $\begin{array}{l}\text { humuszos réteg vastagsága szerint: } \\
\text { sekély }-<30 \mathrm{~cm} \\
\text { közepes }-30-60 \mathrm{~cm} \\
\text { mély }->60 \mathrm{~cm} \\
\text { humusztartalom szerint: } \\
\text { gyengén humuszos }-<1,5 \% \text { humusz } \\
\text { erösen humuszos }- \text { humusz }>3 \%\end{array}$ \\
\hline \multirow{3}{*}{$\begin{array}{l}\text { Savanyú nem } \\
\text { podzolos } \\
\text { erdőtalaj } \\
(\text { SNBET) }\end{array}$} & - & - \\
\hline & \multirow[t]{2}{*}{-} & $\begin{array}{l}\text { savanyú humuszos - acid mull } \\
\text { nyers humuszos - moder }\end{array}$ \\
\hline & & $\begin{array}{l}\text { humuszos réteg vastagsága szerint: } \\
\text { sekély }-<30 \mathrm{~cm} \\
\text { közepes }-30-60 \mathrm{~cm} \\
\text { mély }->60 \mathrm{~cm} \\
\text { humusztartalom szerint: } \\
\text { gyengén humuszos }-<1,5 \% \text { humusz } \\
\text { erősen humuszos }- \text { humusz }>3 \%\end{array}$ \\
\hline
\end{tabular}




\begin{tabular}{|c|c|c|}
\hline \multicolumn{3}{|c|}{ 5. táblázat folytatása } \\
\hline \multirow{3}{*}{$\begin{array}{l}\text { Agyagbemosó } \\
\text { dásos } \\
\text { erdőtalaj } \\
\text { (ABET) }\end{array}$} & $\begin{array}{l}\text { Az Asz szint humusztartalma } \\
\text { ritkán haladja meg a } 2 \% \text {-ot }\end{array}$ & - \\
\hline & - & - \\
\hline & & $\begin{array}{l}\text { humuszos réteg vastagsága szerint: } \\
\text { sekély }-<30 \mathrm{~cm} \\
\text { közepes }-30-60 \mathrm{~cm} \\
\text { mély }->60 \mathrm{~cm} \\
\text { humusztartalom szerint: } \\
\text { gyengén humuszos }-<1,5 \% \text { humusz } \\
\text { erösen humuszos }- \text { humusz }>3 \%\end{array}$ \\
\hline \multirow{3}{*}{$\begin{array}{l}\text { Podzolos } \\
\text { barna } \\
\text { erdőtalaj } \\
\text { (PBET) }\end{array}$} & $\begin{array}{l}\text { kb. } 10 \mathrm{~cm} \text { vastag humuszt } \\
\text { tartalmazó felszíni szint }\end{array}$ & - \\
\hline & & \\
\hline & & $\begin{array}{l}\text { humuszos réteg vastagsága szerint: } \\
\text { sekély }-<20 \mathrm{~cm} \\
\text { közepes }-20-40 \mathrm{~cm} \\
\text { mély }->40 \mathrm{~cm} \\
\text { humusztartalom szerint: } \\
\text { gyengén humuszos }-<1,5 \% \text { humusz } \\
\text { erősen humuszos }- \text { humusz }>3 \%\end{array}$ \\
\hline \multirow{3}{*}{$\begin{array}{l}\text { Pangóvizes } \\
\text { barna } \\
\text { erdőtalaj } \\
\text { (PaBET) }\end{array}$} & - & - \\
\hline & - & - \\
\hline & & $\begin{array}{l}\text { humuszos réteg vastagsága szerint: } \\
\text { sekély }-<30 \mathrm{~cm} \\
\text { közepes }-30-60 \mathrm{~cm} \\
\text { mély }->60 \mathrm{~cm} \\
\text { humusztartalom szerint: } \\
\text { gyengén humuszos }-<1,5 \% \text { humusz } \\
\text { erősen humuszos }- \text { humusz }>3 \%\end{array}$ \\
\hline \multirow{3}{*}{$\begin{array}{l}\text { Kovárványos } \\
\text { barna } \\
\text { erdőtalaj } \\
\text { (KBET) }\end{array}$} & $\begin{array}{l}\text { Szervesanyag tartalmuk ritkán } \\
\text { haladja meg a } 2 \% \text {-ot }\end{array}$ & - \\
\hline & $\begin{array}{l}\text { Humusz kovárványos }- \text { ha a } \\
\text { kovárványcsíkok }\end{array}$ & $\begin{array}{l}\text { humuszos - enyhén humuszosodott B1 } \\
\text { szint, barnás kovárvány csíkokkal }\end{array}$ \\
\hline & & $\begin{array}{l}\text { humuszos réteg vastagsága szerint: } \\
\text { sekély }-<20 \mathrm{~cm} \\
\text { közepes }-20-40 \mathrm{~cm} \\
\text { mély }->40 \mathrm{~cm} \\
\text { humusztartalom szerint: } \\
\text { erösen humuszos - humusz }>3 \%\end{array}$ \\
\hline
\end{tabular}

\section{Szikes talajok}

A Szikes talajok esetében az osztályozás típus szintjén sem leíró jellegű, sem számszerüen meghatározott szervesanyagra vonatkozó osztályozási információ nincs definiálva egyik útmutatónkban sem. 
A „Nagyméretarányú útmutató”-ban (JASSÓ et al., 1989) altípus, az „Üzemi genetikus útmutató"-ban (SZABOLCS, 1966) változati szinten a humuszos réteg vastagságára vonatkozóan kerültek meghatározásra számszerü határértékek - de a kritériumok az egyes útmutatók között eltérnek (6. táblázat), a humusztartalom jelzése pedig nem megoldott.

\section{6. táblázat}

A Szikes talajok szervesanyagra vonatkozó osztályozási információi a hazai genetikus osztályozási rendszer útmutatóiban (SZABOLCS, 1966; JASSÓ et al., 1989 alapján)

\begin{tabular}{|c|c|c|}
\hline \multirow{4}{*}{$\begin{array}{l}\text { A szikes } \\
\text { talajok } \\
\text { talajtípusai }\end{array}$} & \multicolumn{2}{|c|}{ Szervesanyagra vonatkozó osztályozási információk } \\
\hline & $\begin{array}{c}\text { Nagyméretarányú útmutató } \\
\text { JASSÓ et al. (1989) }\end{array}$ & $\begin{array}{c}\text { Üzemi genetikus útmutató } \\
\text { SZABOLCS (1966) }\end{array}$ \\
\hline & talajtípus & talajtípus \\
\hline & altípus & altípus \\
\hline Szoloncsák & - & - \\
\hline (Sz) & - & \\
\hline Réti szolonyec & - & - \\
\hline$(\mathrm{RSz})$ & $\begin{array}{l}\text { Kérges }- \text { A szint } 0-7 \mathrm{~cm} \\
\text { Közepes }- \text { A szint } 7-20 \mathrm{~cm} \\
\text { Mély }- \text { A szint }>20 \mathrm{~cm}\end{array}$ & $\begin{array}{l}\text { Kérges - A szint } 0-7 \mathrm{~cm} \\
\text { Közepes }- \text { A szint } 7-15 \mathrm{~cm} \\
\text { Mély - A szint }>15 \mathrm{~cm}\end{array}$ \\
\hline Szoloncsák- & - & - \\
\hline $\begin{array}{l}\text { szolonyec } \\
(\mathrm{SzSz})\end{array}$ & - & \\
\hline Másodlagosan & - & - \\
\hline $\begin{array}{l}\text { elszikesedett } \\
\text { talajok (MSz) }\end{array}$ & - & $\begin{array}{l}\text { Szoloncsákok, réti szolonyecek változati } \\
\text { tulajdonságai }\end{array}$ \\
\hline Sztyeppesedő & - & - \\
\hline $\begin{array}{l}\text { réti szolonyec } \\
\text { (SzRSz) }\end{array}$ & $\begin{array}{l}\text { Közepes }- \text { A szint }<25 \mathrm{~cm} \\
\text { Mély }- \text { A szint }>25 \mathrm{~cm}\end{array}$ & $\begin{array}{l}\text { Közepes }- \text { A szint }<20 \mathrm{~cm} \\
\text { Mély - A szint }>20 \mathrm{~cm}\end{array}$ \\
\hline
\end{tabular}

\section{Réti talajok}

A Réti talajok keletkezésében meghatározó időszakos túlnedvesedés általában nagyobb mértékủ szervesanyag felhalmozódást, és a humuszos réteg egyedi morfológiai bélyegeinek (sötétebb, szürkésfekete szín, éles alsó átmenet) kialakulását eredményezte. Genetikus osztályozásunk típus szintjén az említett réti bélyegek mindegyike leíró jellegü, és gyakori a szervesanyag-tartalomra vonatkozó „elég nagy”, „némileg alacsonyabb”, ,általában” vagy „,a típuson belül egyaránt nagyon különbözö" kifejezések használata (7. táblázat). 


\section{7. táblázat}

A Réti talajok szervesanyagra vonatkozó osztályozási információi a hazai genetikus osztályozási rendszer útmutatóiban (SZABOLCS, 1966; JASSó et al., 1989 alapján)

\begin{tabular}{|c|c|c|}
\hline \multirow{5}{*}{$\begin{array}{l}\text { A Réti } \\
\text { talajok } \\
\text { talajtípusai }\end{array}$} & \multicolumn{2}{|c|}{ Szervesanyagra vonatkozó osztályozási információk } \\
\hline & $\begin{array}{c}\text { Nagyméretarányú útmutató } \\
\text { JASSÓ et al. (1989) }\end{array}$ & $\begin{array}{l}\text { Üzemi genetikus útmutató } \\
\text { SZABOLCS (1966) }\end{array}$ \\
\hline & talajtípus & talajtípus \\
\hline & altípus & altípus \\
\hline & & változat \\
\hline Szoloncsákos & - & - \\
\hline & - & \\
\hline$(\mathrm{SzkR})$ & & $\begin{array}{l}\text { humuszos réteg vastagsága szerint: } \\
\text { sekély }-<40 \mathrm{~cm} \\
\text { közepes }-40-80 \mathrm{~cm} \\
\text { mély }->80 \mathrm{~cm}\end{array}$ \\
\hline Szolonyeces & - & $\therefore$ \\
\hline réti talaj & - & \\
\hline (SznyR) & & $\begin{array}{l}\text { humuszos réteg vastagsága szerint: } \\
\text { sekély }-<40 \mathrm{~cm}(\mathrm{~A}+\mathrm{B} \text { szint }) \\
\text { közepes }-40-80 \mathrm{~cm} \\
\text { mély }->80 \mathrm{~cm}\end{array}$ \\
\hline $\begin{array}{ll}\text { Típusos } & \text { réti } \\
\text { talaj (TR) }\end{array}$ & Sötétszürke, szürkésfekete A szint & $\begin{array}{l}\text { Elég nagy humusztartalmú } \mathrm{A}+\mathrm{B} \text { szint, } \\
\text { viszonylag rövid átmenettel }\end{array}$ \\
\hline & - & \\
\hline & & $\begin{array}{l}\text { humuszos réteg vastagsága szerint: } \\
\text { sekély }-<40 \mathrm{~cm}(\mathrm{~A}+\mathrm{B} \text { szint }) \\
\text { közepes }-40-80 \mathrm{~cm} \\
\text { mély }->80 \mathrm{~cm} \\
\text { humusztartalom szerint: } \\
\text { gyengén humuszos }- \text { humusz }<2 \text {; } \\
\text { homok esetén }<1,5 \%\end{array}$ \\
\hline $\begin{array}{|ll|}\text { Lápos } & \text { réti } \\
\text { talaj (LR) } & \end{array}$ & $\begin{array}{l}\text { Humuszos rétegük vastagsága és a } \\
\text { szervesanyag-tartalom } \begin{array}{l}\text { egyaránt } \\
\text { nagyon különböző, ált. } \\
\text { közötti }\end{array}\end{array}$ & $\begin{array}{l}\text { Magas } \\
\text { kotusodás }\end{array}$ \\
\hline & - & \\
\hline & & $\begin{array}{l}\text { sekély }-<40 \mathrm{~cm}(\mathrm{~A}+\mathrm{B} \text { szint }) \\
\text { közepes }-40-80 \mathrm{~cm} \\
\text { mély }->80 \mathrm{~cm}\end{array}$ \\
\hline
\end{tabular}




\begin{tabular}{|c|c|c|}
\hline \multicolumn{3}{|c|}{ 7. táblázat folytatása } \\
\hline $\begin{array}{l}\text { Csernozjom } \\
\text { réti talaj (CsR) }\end{array}$ & $\begin{array}{l}\text { A humusztartalom némileg } \\
\text { alacsonyabb, mint a réti talajoknál, } \\
\text { átmenete megnyúlik }\end{array}$ & $\begin{array}{l}\text { Némileg } \\
\text { humusztartalom, barnásszürke szín, } \\
\text { megnyúló átmenet a típusos réti } \\
\text { talajhoz képest }\end{array}$ \\
\hline & - & $\begin{array}{l}\text { humuszos réteg vastagsága szerint: } \\
\text { sekély }-<40 \mathrm{~cm}(\mathrm{~A}+\mathrm{B} \text { szint }) \\
\text { közepes }-40-80 \mathrm{~cm} \\
\text { mély }->80 \mathrm{~cm} \\
\text { humusztartalom szerint: } \\
\text { gyengén humuszos }- \text { humusz }<2 \text {; } \\
\text { homok esetén }<1,5 \%\end{array}$ \\
\hline $\begin{array}{l}\text { Öntés réti talaj } \\
\text { (ÖR) }\end{array}$ & $\begin{array}{l}\text { Humuszos szintjük kevésbé } \\
\text { kialakult, mint a réti talajoknál }\end{array}$ & Gyakran elég mély humuszos réteg \\
\hline & - & $\begin{array}{l}\text { humuszos réteg vastagsága szerint: } \\
\text { sekély }-<40 \mathrm{~cm}(\mathrm{~A}+\mathrm{B} \text { szint }) \\
\text { közepes }-40-80 \mathrm{~cm} \\
\text { mély }->80 \mathrm{~cm} \\
\text { humusztartalom szerint: } \\
\text { gyengén humuszos }- \text { humusz }<2 \text {; } \\
\text { homok esetén }<1,5 \%\end{array}$ \\
\hline
\end{tabular}

Az „Üzemi genetikus útmutató”-ban (SzABOLCS, 1966) a réti talajtípusok kapcsán megadott humuszréteg vastagság értékek (változati szint) megegyeznek a Csernozjom talajok típusainál (4. táblázat) megadott értékekkel. A humusztartalom jelzése is a Csernozjom fötípuséhoz hasonló, csak a „gyengén humuszos” jelleg jelezhető (szintén az azonos értelmezést nehezítő, textúra függvényében külön definiált határértékekkel), így a szervesanyag-tartalom pontosabb jelzésére a réti talajok esetében sincs mód.

\section{8. táblázat}

A Mocsári és ártéri erdők talajainak szervesanyagra vonatkozó osztályozási információi a hazai genetikus osztályozási rendszer útmutatóiban

(SZABOLCS, 1966; JASSÓ et al., 1989 alapján)

\begin{tabular}{|c|c|c|}
\hline \multirow{4}{*}{$\begin{array}{l}\text { A Mocsári és ártéri } \\
\text { erdők talajainak } \\
\text { talajtípusai }\end{array}$} & \multicolumn{2}{|c|}{ Szervesanyagra vonatkozó osztályozási információk } \\
\hline & $\begin{array}{c}\text { Nagyméretarányú útmutató } \\
\text { JASSÓ et al. (1989) }\end{array}$ & $\begin{array}{c}\text { Üzemi genetikus útmutató } \\
\text { SZABOLCS (1966) }\end{array}$ \\
\hline & Talajtípus & talajtípus \\
\hline & Altípus & altípus \\
\hline $\begin{array}{l}\text { Mocsári és ártéri erdők } \\
\text { talajai (MÁET) }\end{array}$ & gyengén fejlett humuszréteg & \\
\hline
\end{tabular}




\section{Mocsári és ártéri erdők talajai}

A Mocsári és ártéri erdők talajainak jellemző szervesanyag tartalmáról csak a „Nagyméretarányú útmutató” (JASSÓ et al., 1989) ad leíró jellegű információt - de a „gyengén fejlett humuszréteg”-nek sem a színe, sem vastagsága, sem szervesanyagtartalma nem definált (8. táblázat).

\section{9. táblázat}

A Folyóvizek, tavak üledékeinek és lejtők hordalékainak szervesanyagra vonatkozó osztályozási információi a hazai genetikus osztályozási rendszer útmutatóiban (SZABOLCS, 1966; JASsó et al., 1989 alapján)

\begin{tabular}{|c|c|c|}
\hline \multirow{4}{*}{$\begin{array}{l}\text { A Folyóvizek, } \\
\text { tavak } \\
\text { üledékeinek } \\
\text { és lejtők } \\
\text { hordalékaina } \\
\text { k talajtípusai }\end{array}$} & \multicolumn{2}{|c|}{ Szervesanyagra vonatkozó osztályozási információk } \\
\hline & $\begin{array}{c}\text { Nagyméretarányú útmutató } \\
\text { JASSÓ et al. (1989) }\end{array}$ & $\begin{array}{c}\text { Üzemi genetikus útmutató } \\
\text { SZABOLCS (1966) }\end{array}$ \\
\hline & Talajtípus & talajtípus...... \\
\hline & Altípus & altípus \\
\hline \multirow{2}{*}{$\begin{array}{l}\text { Nyers } \\
\text { öntéstalaj } \\
\text { (NyÖ) }\end{array}$} & $\begin{array}{l}\text { jelentéktelen } \\
\text { humusz }<1 \%\end{array}$ & $\begin{array}{l}\text { jelentéktelen humuszosodás, humusz } \\
<1 \%\end{array}$ \\
\hline & $\begin{array}{l}\text { többrétegú }- \text { eltemetett } \\
\text { (humuszos vagy humusz nélküli) } \\
\text { talaj } 150 \mathrm{~cm} \text {-en belül }\end{array}$ & $\begin{array}{l}\text { többrétegü }- \text { eltemetett talaj } 2 \mathrm{~m} \text {-en } \\
\text { belül }\end{array}$ \\
\hline \multirow{3}{*}{$\begin{array}{l}\text { Humuszos } \\
\text { öntéstalaj } \\
\text { (HÖ) }\end{array}$} & $\begin{array}{l}\text { humuszos réteg megjelenése, } \\
\text { humusz }>1 \%\end{array}$ & $\begin{array}{l}\text { humuszos réteg megjelenése, humusz } \\
1-3 \%\end{array}$ \\
\hline & $\begin{array}{l}\text { többrétegú }-\quad \text { eltemetett } \\
\text { (humuszos vagy humusz nélküli) } \\
\text { talaj } 150 \mathrm{~cm} \text {-en belül }\end{array}$ & $\begin{array}{l}\text { többrétegü - eltemetett talaj } 2 \mathrm{~m} \text {-en } \\
\text { belül } \\
\text { réti jellegü - humusztartalom eléri a } \\
3 \% \text { körüli értéket }\end{array}$ \\
\hline & $\begin{array}{l}\text { Réti öntés - elörehaladottabb } \\
\text { humuszosodás }\end{array}$ & $\begin{array}{l}\text { humuszos réteg vastagsága szerint: } \\
\text { sekély }-<30 \mathrm{~cm}(\mathrm{~A}+\mathrm{B} \text { szint }) \\
\text { közepes }-30-60 \mathrm{~cm} \\
\text { mély }->60 \mathrm{~cm} \\
\text { humusztartalom szerint: } \\
\text { gyengén humuszos }- \text { humusz } \\
<1,5 \%\end{array}$ \\
\hline \multirow{2}{*}{$\begin{array}{l}\text { Lejtőhordalék } \\
\text { talaj } \\
\text { (LH) }\end{array}$} & $\begin{array}{l}\text { a humuszos anyag vastagsága az } \\
1,5-2 \mathrm{~m} \text { - } \mathrm{t} \text { is elérheti }\end{array}$ & $\begin{array}{lll}\text { változatos } & \text { humusztartalom } & \text { és } \\
\text { vastagság }\end{array}$ \\
\hline & & $\begin{array}{l}\text { humuszos réteg vastagsága szerint: } \\
\text { sekély }-<40 \mathrm{~cm}(\mathrm{~A}+\mathrm{B} \text { szint }) \\
\text { közepes }-40-80 \mathrm{~cm} \\
\text { mély }->80 \mathrm{~cm}\end{array}$ \\
\hline
\end{tabular}


Folyóvizek, tavak üledékeinek és lejtők hordalékainak talajai

A Folyóvizek, tavak üledékeinek és lejtők hordalékainak talajai esetében a nyers-, és humuszos öntéstalaj elkülönítése mindkét útmutatóban 1\%-os humusztartalom határérték alapján történik. A humuszos öntések réti jellegü altípusainak meghatározása azonban már erősen szubjektív (9. táblázat), és az „elörehaladottabb" humuszosodás mértékének jelzésére nincsen mód.

A Lejtőhordalék talajok esetében az útmutatók „változatos humusztartalom”ról és a humuszos réteg „,változatos vastagság”-áról számolnak be, de a talajtípusra gyakran jellemző, akár jelentős mértéket is elérő szervesanyag felhalmozódás jelzésére csak az „Üzemi genetikus útmutató”(SzABOLCS, 1966) változati szintjén, a humuszos réteg vastagság megadásával van mód, a szervesanyag-tartalom jelzése nem megoldott (9. táblázat).

\section{Értékelés és javaslatok}

A hazai genetikus osztályozás gyakorlatban alkalmazott útmutatóinak (SZABOLCS, 1966; JASSÓ et al., 1989) áttekintése és elemzése alapján megállapítható, hogy genetikus osztályozásunk a talajok szervesanyag tartalmára, ill. a szervesanyagot tartalmazó rétegek vastagságára, és egyéb, kapcsolódó morfológiai tulajdonságaira (pl. szín, szintek közötti átmenet) vonatkozóan gyakran leíró jellegü, szubjektív információkat tartalmaz, megnehezítve a talajtípusok egymástól való elkülönítését, és pontos, számszerủ adatokkal alátámasztott jellemzését.

A leírásokban gyakoriak az osztályozási bizonytalanságot növelö kifejezések (pl. ,„általában”, „,elég nagy”, ,ritkán haladja meg”, vagy „előfordul”), és a típusok fótípuson belüli, de számszerü alapokat nélkülözö összehasonlítása is (pl. „humusztartalom némileg alacsonyabb, mint”, vagy „humuszos szintjük kevésbé kialakult, mint").

Egyes típusoknál leíró jellegủ információk mellett a mennyiségre, vagy mélységre vonatkozó értékek, esetenként mindkettő megtalálható, leggyakrabban intervallumok formájában - de számszerü információk jelzésére a legtöbb esetben csak az osztályozás legalacsonyabb, változati szintjén van lehetőség.

A „humuszos”jelző használata sem konzekvens, bizonyos esetekben talajtípust (pl. humuszos homok, humuszon öntés), míg más esetekben altípust (pl. humuszos kovárványos barna erdőtalaj), vagy változatot (pl. gyengén humuszos barnaföld) különböztet meg.

$\mathrm{Az}$ osztályozás alacsonyabb szintjein számszerủ határértékekkel meghatározott, a humuszos réteg vastagságára, ill. a humusztartalomra vonatkozó altípus-, ill. változati tulajdonságok az említett tulajdonságokra vonatkozó pontos alapdefiníciók hiányában is tovább növelik a szubjektivitás mértékét. A „humuszos réteg vastagságának" objektív megállapításához szükséges lenne a humuszosnak tekinthető réteg színének pontos, Munsell színskála szerint történő definiálására; a „humusztartalom” szerinti osztályozáshoz pedig a vizsgált rétegvastagság azonos értelmezésére. 
További problémát okoz az említett mélységre (vékony, sekély, közepes, mély), és humusztartalomra (gyengén-, ill erősen humuszos, humuszgazdag) vonatkozó elnevezések főtípusonként/típusonként eltérő meghatározása (10-11-12. táblázat, ill. 13-14. táblázat), és a kapcsolódó határértékek egyes források (SZABOLCS, 1966; JASSÓ et al., 1989) közötti eltérése. Ez megnehezíti a két fontos szervesanyagra vonatkozó paraméter (mennyiség, mélység) egységes értékelését, és az erre vonatkozó információ közlését.

\section{0. táblázat}

A „Mély humuszos rétegü” elnevezés kapcsán megjelenő eltérő osztályozási kritériumok a hazai genetikus osztályozási rendszer változati szintjén ásványi talajaink típusaiban (SZABOLCS, 1966 alapján). A fötípusok rövidítései a 2-9. táblázatokban találhatóak.

\begin{tabular}{|c|c|c|c|c|c|c|c|c|}
\hline \multirow[b]{2}{*}{ 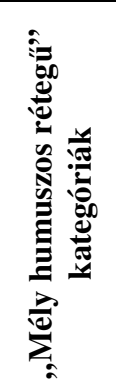 } & \multicolumn{8}{|c|}{ Genetikus fötípusok és talajtípusaik } \\
\hline & 告 & 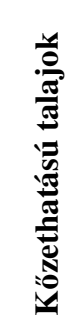 & 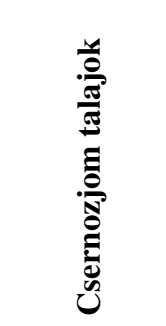 & 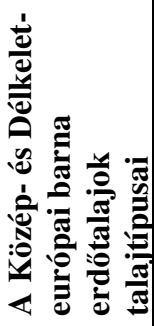 & 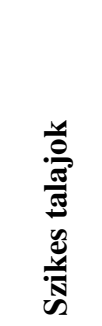 & 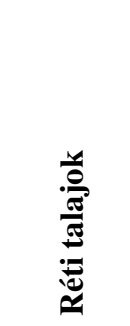 & 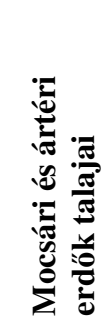 & 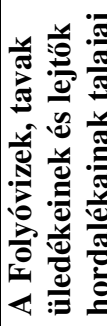 \\
\hline - & $\begin{array}{l}\text { KSz, K, } \\
\text { FH, FK }\end{array}$ & $\begin{array}{c}\mathrm{HK}, \\
\mathrm{Ra}\end{array}$ & & & $\begin{array}{c}\mathrm{Sz}, \\
\mathrm{SzSz}\end{array}$ & & MÁET & NyÖ \\
\hline$>15 \mathrm{~cm}$ & & & & & $\mathrm{RSz}$ & & & \\
\hline$>20 \mathrm{~cm}$ & & & & & SzRSz & & & \\
\hline$>40 \mathrm{~cm}$ & & & & $\begin{array}{c}\text { PoBET, } \\
\text { KBET }\end{array}$ & & & & \\
\hline$>50 \mathrm{~cm}$ & $\mathrm{HH}$ & & & & & & & \\
\hline$>60 \mathrm{~cm}$ & & & & $\begin{array}{c}\text { CsBET, } \\
\text { BF, } \\
\text { SNBET, } \\
\text { ABET, } \\
\text { PaBET }\end{array}$ & & & & HÖ \\
\hline$>80 \mathrm{~cm}$ & & & $\begin{array}{l}\text { ECs, MCs, } \\
\text { KCs, RCs, } \\
\text { ÖCs }\end{array}$ & & & $\begin{array}{c}\text { SzkR, } \\
\text { SznyR, } \\
\text { TR, LR, } \\
\text { CsR, ÖR }\end{array}$ & & LH \\
\hline $\begin{array}{c}>100 \\
\mathrm{~cm}\end{array}$ & & $\begin{array}{l}\mathrm{Re}, \\
\mathrm{FNy}\end{array}$ & & & & & & \\
\hline
\end{tabular}

A „Mély humuszos rétegü” változati tulajdonság (SzABOLCS, 1966) hét; a „Közepes humuszos rétegü” nyolc; míg a „Sekély humuszos rétegü” öt különböző mélységre vagy mélységi intervallumra vonatkozhat (10-11-12. táblázat), számos fötípus esetében még fötípuson belül sem egyöntetűen használt, ill. egyes talajtípusok esetében nem is jelezhetö. 
A „Mély humuszos réteg” jelenléte (különböző fôtípusok és talajtípusok esetén) vonatkozhat $15 \mathrm{~cm}$-t, és $100 \mathrm{~cm}$-t meghaladó humuszos réteg vastagságra, a „Közepes humuszos réteg” 7-100 cm között; míg a „Sekély humuszos réteg” 50 és $20 \mathrm{~cm}$ között változhat. A Földeskopárok esetében egyedi megjelenésként a „Vékony humuszos rétegü” elnevezés is használatos $(20 \mathrm{~cm}$-nél vékonyabb humuszos réteg vastagság esetében) - amely még fötípuson belül is átfedést mutat a „Vékony humuszos rétegü humuszos homok" talajok esetében megadott határértékkel.

\section{1. táblázat}

A „Közepes humuszos rétegü” elnevezés kapcsán megjelenő eltérő osztályozási kritériumok a hazai genetikus osztályozási rendszer változati szintjén ásványi talajaink típusaiban

(SZABOLCS, 1966 alapján). A fötípusok rövidítései a 2-9. táblázatokban találhatóak.

\begin{tabular}{|c|c|c|c|c|c|c|c|c|}
\hline \multirow[b]{2}{*}{ 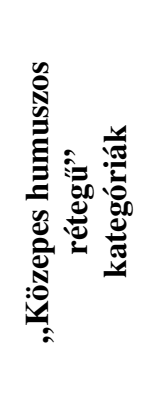 } & \multicolumn{8}{|c|}{ Genetikus fötípusok és talajtípusaik } \\
\hline & 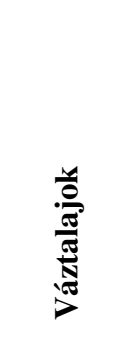 & 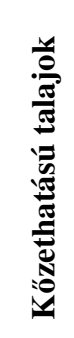 & 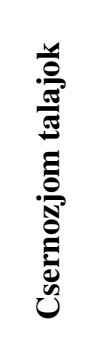 & 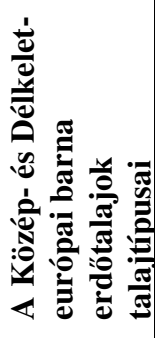 & 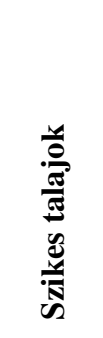 & 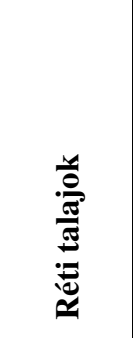 & 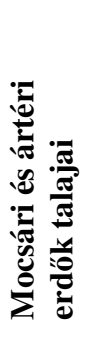 & 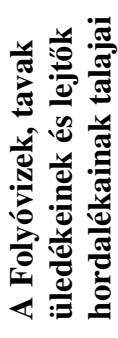 \\
\hline- & $\begin{array}{l}\text { KSz, K, } \\
\text { FH, FK }\end{array}$ & $\mathrm{Ra}$ & & & $\begin{array}{c}\mathrm{Sz}, \\
\mathrm{SzSz}\end{array}$ & & & NyÖ \\
\hline $7-15 \mathrm{~cm}$ & & & & & $\mathrm{RSz}$ & & & \\
\hline$<20 \mathrm{~cm}$ & & & & & SzRSz & & & \\
\hline $20-50 \mathrm{~cm}$ & $\mathrm{HH}$ & & & & & & & \\
\hline $20-40 \mathrm{~cm}$ & & & & $\begin{array}{c}\text { PoBET, } \\
\text { KBET }\end{array}$ & & & & \\
\hline $30-60 \mathrm{~cm}$ & & & & $\begin{array}{c}\text { CsBET, } \\
\text { BF, } \\
\text { SNBET, } \\
\text { ABET, } \\
\text { PaBET } \\
\end{array}$ & & & & нÖ \\
\hline $40-80 \mathrm{~cm}$ & & & $\begin{array}{l}\text { ECs, } \\
\text { MCs, } \\
\text { KCs, } \\
\text { RCs, } \\
\text { ÖCs }\end{array}$ & & & $\begin{array}{c}\text { SzkR, } \\
\text { SznyR, } \\
\text { TR, LR, } \\
\text { CsR, } \\
\text { ÖR }\end{array}$ & & LH \\
\hline$>50 \mathrm{~cm}$ & & $\mathrm{HK}$ & & & & & & \\
\hline $\begin{array}{c}50-100 \\
\mathrm{~cm}\end{array}$ & & $\begin{array}{l}\text { Re, } \\
\text { FNy }\end{array}$ & & & & & & \\
\hline
\end{tabular}


12. táblázat

A „Sekély humuszos rétegü” elnevezés kapcsán megjelenő eltérő osztályozási kritériumok a hazai genetikus osztályozási rendszer változati szintjén ásványi talajaink típusaiban (SZABOLCS, 1966 alapján). A fötípusok rövidítései a 2-9. táblázatokban találhatóak.

\begin{tabular}{|c|c|c|c|c|c|c|c|c|}
\hline \multirow[b]{2}{*}{ 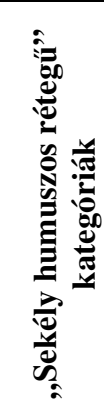 } & \multicolumn{8}{|c|}{ Genetikus fótípusok és talajtípusaik } \\
\hline & 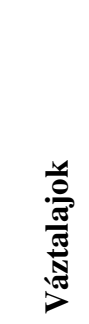 & 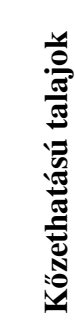 & 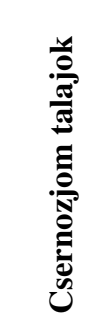 & 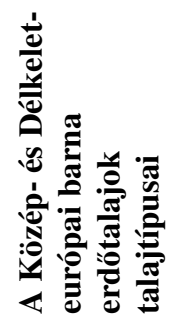 & 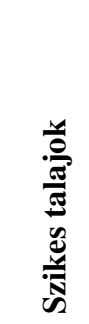 & 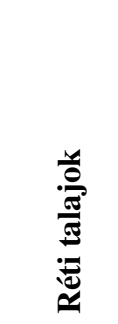 & 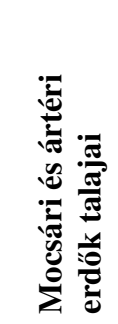 & 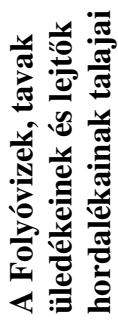 \\
\hline - & $\begin{array}{c}\mathrm{KSz}, \\
\mathrm{K}, \\
\mathrm{FH}\end{array}$ & $\mathrm{Ra}$ & & & $\begin{array}{l}\text { Sz, } \\
\text { SzSz }\end{array}$ & & MÁET & NyÖ \\
\hline $\begin{array}{l}<20 \\
\mathrm{~cm}\end{array}$ & $\mathrm{HH}$ & & & $\begin{array}{c}\text { PoBET, } \\
\text { KBET }\end{array}$ & & & & \\
\hline $\begin{array}{l}<30 \\
\mathrm{~cm}\end{array}$ & & & & $\begin{array}{c}\text { CsBET, } \\
\text { BF, } \\
\text { SNBET, } \\
\text { ABET, } \\
\text { PaBET }\end{array}$ & & & & HÖ \\
\hline $\begin{array}{c}20-40 \\
\mathrm{~cm}\end{array}$ & $\mathrm{FK}^{*}$ & & & & & & & \\
\hline $\begin{array}{c}<40 \\
\mathrm{~cm}\end{array}$ & & & $\begin{array}{l}\text { ECs, } \\
\text { MCs, } \\
\text { KCs, } \\
\text { RCs, } \\
\text { ÖCs }\end{array}$ & & & $\begin{array}{c}\text { SzkR, } \\
\text { SznyR, } \\
\text { TR, } \\
\text { LR, } \\
\text { CsR, } \\
\text { ÖR }\end{array}$ & & LH \\
\hline $\begin{array}{l}<50 \\
\mathrm{~cm}\end{array}$ & & $\begin{array}{c}\text { HK, } \\
\text { Re, } \\
\text { FNy }\end{array}$ & & & & & & \\
\hline
\end{tabular}

* A Földeskopár talajtípus esetében a „sekély humuszos rétegü” intervallum formájában megadott kategória mellett (egyedi megjelenéskét) a „vékony humuszos rétegü" $(20 \mathrm{~cm}$ nél sekélyebb) kategória is megjelenik a SzABOLCS (1966) féle útmutatóban.

A talajok humusztartalmára vonatkozóan az „Erősen humuszos” és a „Gyengén humuszos”, ill. a Rendzina talajtípus esetében (egyedi megjelenésként) a „Humuszgazdag” (>20 \% humusztartalom) elnevezések használhatóak (SZABOLCS, 1966).

Az „Erősen humuszos” változat esetében 2 és $20 \%$ humusztartalom között, összesen négy kategória került meghatározásra (13. táblázat), de mindösszesen 
három fötípus néhány talajtípsa esetében van lehetőség a változati elnevezés használatára.

\section{3. táblázat}

Az „Erősen humuszos” elnevezés kapcsán megjelenő eltérő osztályozási kritériumok a hazai genetikus osztályozási rendszer változati szintjén ásványi talajaink típusaiban (SzABOLCS, 1966 alapján). A főtípusok rövidítései a 2-9. táblázatokban találhatóak.

\begin{tabular}{|c|c|c|c|c|c|c|c|c|}
\hline \multirow[b]{2}{*}{ 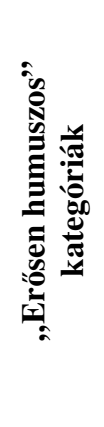 } & \multicolumn{8}{|c|}{ Genetikus fötípusok és talajtípusaik } \\
\hline & 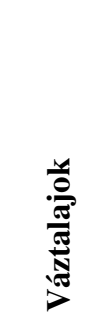 & 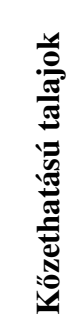 & 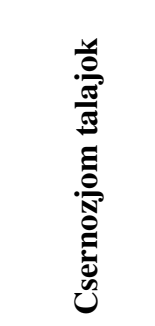 & 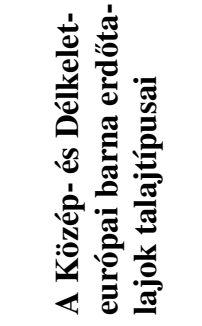 & 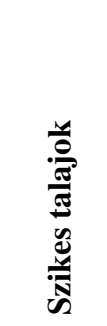 & 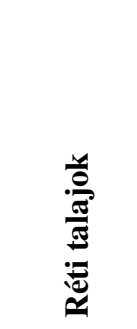 & 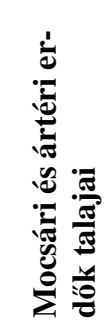 & 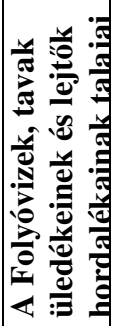 \\
\hline- & $\begin{array}{l}\mathrm{KSz}, \\
\mathrm{K}, \mathrm{FH}, \\
\mathrm{HH}\end{array}$ & $\begin{array}{c}\text { FNy, } \\
\text { Ra }\end{array}$ & $\begin{array}{c}\text { ECs, MCs, } \\
\text { KCs, RCs, } \\
\text { ÖCs }\end{array}$ & CsBET & $\begin{array}{c}\text { Sz, } \\
\text { RSz, } \\
\text { SzSz, } \\
\text { SzRSz }\end{array}$ & $\begin{array}{c}\text { SzkR, } \\
\text { SznyR, } \\
\text { TR, LR, } \\
\text { CsR, ÖR }\end{array}$ & MÁET & $\begin{array}{c}\text { NyÖ, } \\
\text { HÖ, } \\
\text { LH }\end{array}$ \\
\hline$>2 \%$ & FK & & & & & & & \\
\hline$>3 \%$ & & & & $\begin{array}{c}\text { BF, SNBET, } \\
\text { ABET, Po- } \\
\text { BET, PaBET, } \\
\text { KBET }\end{array}$ & & & & \\
\hline$>5 \%$ & & $\mathrm{HK}$ & & & & & & \\
\hline $5-20 \%$ & & $\mathrm{Re}^{*}$ & & & & & & \\
\hline
\end{tabular}

* A Rendzina talajtípus esetében az „erösen humuszos” intervallum formájában megadott kategória mellett (egyedi megjelenésként) a „humuszgazdag” (>20\% humusztartalom) kategória is megjelenik a SzABOLCS (1966) féle útmutatóban.

A „Gyengén humuszos” változat jelzésére két kategória $(<2 \%$ ill. 1,5\% humusztartalom) áll rendelkezésre (14. táblázat). Az elnevezések használatát bonyolítja, hogy két fötípus (csernozjom és réti) esetében textúra alapján (homok szövet esetén) azonos talajípusok „Gyengén humuszos” változatai is jelölhetnek eltérő humusztartalmakat. További problémát okoz, hogy minden főtípuson belül előfordulnak olyan talajtípusok, melyek esetében a „gyengén humuszos” változat nem jelölhetö. 
14. táblázat

A „Gyengén humuszos” elnevezés kapcsán megjelenő eltérő osztályozási kritériumok a hazai genetikus osztályozási rendszer változati szintjén ásványi talajaink típusaiban (SZABOLCS, 1966 alapján). A fötípusok rövidítései a 2-9. táblázatokban találhatóak.

\begin{tabular}{|c|c|c|c|c|c|c|c|c|}
\hline \multirow[b]{2}{*}{ 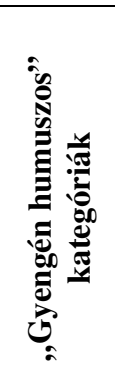 } & \multicolumn{8}{|c|}{ Genetikus fötípusok és talajtípusaik } \\
\hline & 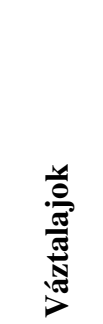 & 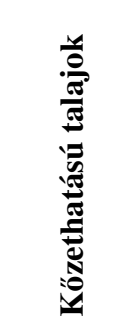 & 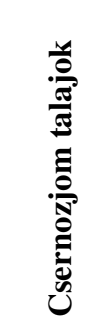 & 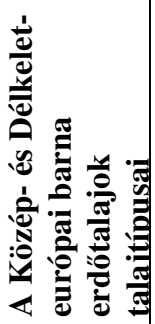 & 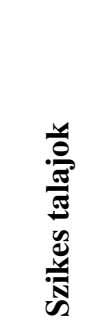 & 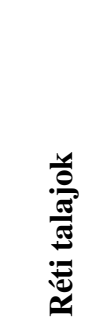 & 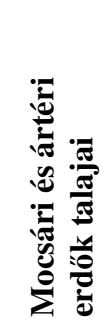 & 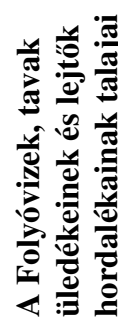 \\
\hline - & $\begin{array}{l}\text { KSz, } \\
\text { K, FH, } \\
\text { FK }\end{array}$ & FNy, Ra & $\mathrm{RCs}$ & KBET & $\begin{array}{c}\text { Sz, } \\
\text { RSz, } \\
\text { SzSz, } \\
\text { SzRSz } \\
\end{array}$ & $\begin{array}{c}\text { SzkR, } \\
\text { SznyR, } \\
\text { LR }\end{array}$ & MÁET & $\begin{array}{l}\text { NyÖ, } \\
\text { LH }\end{array}$ \\
\hline$<2 \%$ & $\mathrm{HH}$ & $\mathrm{HK}, \mathrm{Re}$ & $\begin{array}{l}\text { ECs, } \\
\text { MCs, } \\
\text { KCs, } \\
\text { ÖCs }\end{array}$ & & & $\begin{array}{l}\text { TR, } \\
\text { CsR, } \\
\text { ÖR }\end{array}$ & & \\
\hline$<1,5 \%$ & & & $\begin{array}{l}\text { Homok } \\
\text { szövet } \\
\text { esetén: } \\
\text { MCs, } \\
\text { KCs, } \\
\text { ÖCs }\end{array}$ & $\begin{array}{c}\text { CsBET, } \\
\text { BF, } \\
\text { SNBET, } \\
\text { ABET, } \\
\text { PoBET, } \\
\text { PaBET }\end{array}$ & & $\begin{array}{c}\text { Homok } \\
\text { szövet } \\
\text { esetén: } \\
\text { TR, } \\
\text { CsR, } \\
\text { ÖR }\end{array}$ & & HÖ \\
\hline
\end{tabular}

A felsorolt problémák gyökere kettős lehet. Egyik, hogy az egyes típusokon belül igen eltérő szervesanyag-tartalommal rendelkező talajok fordulhatnak elö, másrészt a genetikus osztályozás fejlesztésének idejében nem állt rendelkezére nagy mennyiségü, egységesen gyüjtött információ a talajegységek tulajdonságainak elemzéséhez.

Javasoljuk a rendelkezésre álló hazai talajadatbázisok numerikus vizsgálata alapján a szervesanyaggal kapcsolatos osztályozási információk felülvizsgálatát, és egységes, azonos értelmezésü, számszerủ határértékekkel és objektív módszerekkel definiált szervesanyag-tartalomra, és humuszos réteg vastagságra vonatkozó kategóriák, ún. diagnosztikus szintek, tulajdonságok és anyagok, valamint altípus és változati tulajdonságok kidolgozását.

Kulcsszavak: talajosztályozás, genetikus szemlélet, szervesanyag, leíró jelleg, szubjektiviás

A kutatást az OTKA 113171 sz. programja támogatta. 


\section{Irodalom}

FuCHS, M., Simon, B., MichÉLI, E., 2005. Soil organic matter as a criteria in soil classification systems. Cereal Research Communications, 33 (1), Proceedings of the IV. Alps-Adria Scientific Workshop Portoroz, Slovenia February $28-$ March 52005 (2005). pp. 365-368.

IUSS Working Group WRB, 2006. World Reference Base for Soil Resources 2006. World Soil Resources Reports No. 103. FAO, Rome.

IUSS WORKING GROUP WRB, 2015. World Reference Base for Soil Resources 2014, update 2015. International soil classification system for naming soils and creating legends for soil maps. World Soil Resources Reports No. 106. FAO, Rome.

JASSÓ F. (szerk.), 1989. Útmutató a nagyméretarányú országos talajtérképezés végrehajtásához. Melioráció - öntözés és talajvédelem.'88 melléklet. Agroinform. Budapest.

LAL, R., 2004a. Soil Carbon Sequestration Impacts on Global Climate Change and Food Security. Science 304. 1623-1627.

LAL, R., 2004b. Soil carbon sequestration to mitigate climate change. Geoderma 123.1-22.

Michéli, E., Fuchs, M., Hegymegi, P., Stefanovits, P., 2006. Classification of the major soils of Hungary and their correlation with the World Reference Base for Soil Resources (WRB). Agrokémia és Talajtan. 55. 19-28.

Michéli, E., Owens, P. R., LÁng, V., Fuchs, M., HemPel, J., 2014. Chapter 4: Organic Carbon as a Major Differentiation Criterion in Soil Classification Systems. In: Hartemink, A., McSweeney, K. (szerk.), Soil Carbon. Progress in Soil Science. Springer. pp. 37-43.

MichÉl, E., Fuchs, M., LÁNG, V., SzEgi, T., Dobos, E., SzABónÉ Kele, G., 2015. Javaslat talajosztályozási rendszerünk megújítására: alapelvek, módszerek, alapegységek. Agrokémia és Talajtan. 64. (1) 285-297.

MichÉl, E., Fuchs, M., Tóth, J. A., CsORBA, Á., SzEGI, T., 2017. Javaslat a hazai láptalajok osztályozásának megújítására. Agrokémia és Talajtan. 66 (1) 183-199.

SOIL SURVEY STAFF, 1999. Soil taxonomy - a basic system of soil classification for making and interpreting soil surveys. Agriculture Handbook No. 436 2nd ed. USDA-NRCS.

SpaARgaren, O. AND F. NACHTERgaele, 1998. Topsoil Characterization for sustainable land management. Land and Water Development Division Soil Resources, Management and Conservation Service, FAO, Rome.

StefAnOVITS, P., 1972. Talajtan. Mezőgazda Kiadó, Budapest.

Stefanovits, P., 1999. A talajok osztályozása. In: Stefanovits, P., FileP, Gy. \& FÜLEKY, Gy. Talajtan. Mezőgazda Kiadó, Budapest. pp. 239-320.

SzABOLCS, I. (szerk.) 1966. A genetikus üzemi talajtérképezés módszerkönyve. OMMI Genetikus Talajtérképek. Ser. 1. No. 9. OMMI. Budapest. 
VÁRALLYAY, GY., 2008. Talaj-víz kölcsönhatások a klímaváltozás tükrében. Talajvédelem Különszám, pp. 17-32.

Open Access nyilatkozat: A cikk a Creative Commons Attribution 4.0 International License (https://creativecommons.org/licenses/by/4.0) feltételei szerint publikált Open Access közlemény, melynek szellemében a cikk bármilyen médiumban szabadon felhasználható, megosztható és újraközölhető, feltéve, hogy az eredeti szerző és a közlés helye, illetve a CC License linkje és az esetlegesen végrehajtott módosítások feltüntetésre kerülnek. (SID_1) 